\title{
Introduction: Commercial Diplomacy and International Business: Merging International Business and International Relations
}

\author{
Donna Lee and Huub Ruël
}

International business has always been intimately linked to the politics of the global economy. Expansion and investment strategies of business play a key role in defining the architecture of the global economy. The shifting dynamic of the global economy such as the emergence of fast growing economies in, for example, India, China, South Africa and Brazil can be partly explained by the emergence of new market players such as the India transnational car manufacturer Tata, as well as the adaptation of established international businesses in the West to the new market opportunities in the South and the East. Equally, the recent (and in places ongoing) economic crises of the West owes as much to the failures of international business notably the banking and investment industry — as it does to the failures of government policy.

At the same time the international political dimension to the global economy explains the regulatory forces which also determine the architecture of the global economy. The far reaching policy liberalization of international trade through international (namely the World Trade Organisation) and regional treaties and rulemaking, and the global deregulation of the investment and financial services sector of the global economy driven by the neoliberal policies of the World Bank and the International Monetary Fund have created economic risks and opportunities for international business by opening up and creating new markets. The strategies of nation states and international business determine the architecture of the global economy and create both economic crises and dynamic growth at one and the same time in the contemporary global economy. So it is that for much of the first decade or so of the new century the West has endured an age of austerity brought on by sustained economic decline and high indebtedness. The once market dominant economies of the United States and West European economies are now struggling to reverse negative economic growth. By contrast large previously peripheral underdeveloped economies in Africa and Asia are enjoying remarkable and sustained growth rates and their exports and investments now fuel an overall growth in the global economy. 


\section{Expansion of Commercial Diplomacy by Nations}

These structural, economic and political developments in the global economy go a long way to explaining the expansion of commercial diplomacy activities by nations. On the one hand, nations use commercial diplomacy to expand trade and investment in the context of declining economic policy sovereignty. The creation of the WTO in 1995 led to an extension of the rules and regulations of international trade and trade-related matters (including the financial services industry). This leaves national economic policy-making severely restricted. Expanding commercial diplomacy to secure new export markets and new inward investments becomes a necessary political tool for nations competing for new markets. When these new markets are in nations where the formal institutional context for doing business is underdeveloped or non-existent or where much of the economy is under state control, the need to expand and develop commercial diplomacy is all the more important.

Major nations in the South and East are now key players and the driving force behind the continuing and increasing economic integration of nations through ageold processes of international trade and foreign direct investment (FDI). Trade and FDI continue to grow, driven by state-led and business-led international entrepreneurship at regional and global levels. Growth in international trade, for example, was $25 \%$ higher in 2010 than in 2009 and driven by the increased demand within large emerging economies in the East and South for energy (oil and gas) and raw commodities such as cotton, nickel and copper. Equally, FDI investment surged as China continued to integrate into African markets. The economic decline of the West in the first decade of this century has been balanced by a remarkable growth in the economies of major states in the South and East. China, Brazil, India and South Africa have become the major engines of growth in the global economy while European economies, along with that of the United States, have declined. The mirrored experience of those nations that have grown economically in the $21 \mathrm{st}$ Century, like China, and those that have declined recently, like most European nations, means that international business becomes ever more significant in the global economy. Chinese investments in Africa have led to the growth of commercial diplomacy between the two to facilitate and manage their economic development. Likewise as economies decline, effective commercial diplomacy becomes ever more important to create new trade and investment opportunities or rescue and nurture existing ones. Thus, whether in the declining West or the emerging South, commercial diplomacy is vital to nations because it is a key component of international trade and FDI which are key economic processes that create capital, products, services and jobs. The ever increasing flows of capital, trade, services, people, ideas and information between states and businesses have increased the need for, and significance of, effective commercial diplomacy to help facilitate continued economic development and market integration as well as manage increased economic risks and opportunities. 


\section{Commercial Diplomacy: The International Relations of Business}

Commercial diplomacy is the international relations of business that knits together political and entrepreneurial activities and agents in the global market. The dynamics in the global economy outlined above - shifting patterns of economic growth and market power from the West to the South as well as the reduced economic policy sovereignty of nations - enhance the need for effective commercial diplomacy and more integrated relations between business and diplomatic officials within the state. It is in this dynamic market and economic policy context that this book seeks to explore the practices of contemporary commercial diplomacy.

What is interesting from our perspective - that is a perspective that combines business studies and political science - is the extent to which commercial diplomacy involves the weaving together of the activities and interests of the nation state and international business, that is the public and the private in the global economy. This is because commercial diplomacy involves and creates networks of nation state (public) and business (private) actors working in domestic, regional and systemic environments in pursuit of private as well as public interests. ${ }^{1}$ Economic integration of the sort now being seen between, for example, China and Africa is regarded to increase economic and political vulnerability and/or open up new economic opportunities for trade and investment growth between their economies as well as closer international political relations between the two nations.

Throughout the last two decades many governments have increased commercial diplomatic activities by increasing state funding for export and investment support and by formally drawing in business into foreign ministries and overseas embassies to bolster entrepreneurial skills and develop entrepreneurial networks. Responding to competitive pressures and the need to find and exploit new markets for domestic goods and services, commercial diplomacy primarily involves export and investment support and advocacy for domestic business. Commercial diplomacy focuses on building networks of diplomats and business groups based in overseas missions to promote trade and investment as well as business advocacy. For many developing countries, commercial diplomacy also includes tourism promotion as a primary activity. Diplomatic networks provide commercial intelligence, tourism marketing, business links and partner searches, as well as business assistance. Conceptually, studies of commercial diplomacy point to complex organizational networks involving ministries of commerce (often with trade promotion agencies/departments), trade and finance, in addition to the foreign ministry. Business groups are also, not surprisingly, key players in these networks and in many cases are formally placed into overseas missions and consuls through secondment programmes. ${ }^{2}$ Business involvement is also channelled through other government departments as well as though links with national and local chambers of commerce. In this conceptualization of commercial

\footnotetext{
${ }^{1}$ See Pigman (2005) for a detailed discussion of some of the new non-state actors in economic diplomacy. ${ }^{2}$ See Lee (2004) for details of the UK experience of this.
} 
diplomacy, business actors are merged with the state rather than autonomous and as such both public and private interests are included in diplomatic representation.

This book explores the international relations of business by presenting a set of studies of commercial diplomacy in the global economy. In so doing it brings new empirical evidence to the study of commercial diplomacy. It also aims to 'change the conversation' as Colquitt and George (2011) put it by creating a dialogue which incorporates concepts and understandings of commercial diplomacy from both political science/international relations and international business. The business conversation in the field of commercial diplomacy up to date has focused mostly on the role of trade shows and trade missions in export increase andFDI. Further, there is a substantial body of work on corporate political activity and the businessgovernment interface. Primarily, this work seeks aims to understand the businessgovernment interface at the country or state level rather than at the individual or global level. As such, ontologically, it is rendering invisible many commercial activities conducted by not only the business actors that are crucial to contemporary commercial diplomacy but also the public political and economic interests at the heart of international business and commercial diplomacy. These are important limitations of the business studies perspective of commercial diplomacy, a perspective that is overly structural since it draws almost exclusively on econometrics or economics.

This book changes the conversation by understanding the international business government relationship at the meso (foreign post-business level) and at the micro level (individual commercial diplomat/individual international entrepreneur level) or, as political scientists would say, agency level. That is, this book highlights how and explains why individuals matter rather than focusing analysis on structural factors alone. The existing work at the macro/structural level has provided interesting and triggering insights on how government- or state-led commercial services work to increase exports and FDI by, for example, highlighting the role of overseas embassies and consulates in commercial diplomacy, but it will always be limited in its explanatory power if it fails to include analysis of the role that individuals play and the importance of micro-level networks of government and business people.

\section{International Business Meets International Relations: An Interdisciplinary View of Commercial Diplomacy}

International business is vital to nations, to their economies. It brings wealth, it creates jobs, it opens views, it changes mindsets, and it creates economic and social stability. International relations is important to nations too. It establishes relationships between nations, it exchanges political views between nations and it creates stability. International business and international relations are intertwined empirically as politicians need to boost economies through supporting entrepreneurship; international entrepreneurs need politicians and government representatives to get access to foreign markets to deal with legal issues across borders. Especially in an age where countries such as China, India, Brazil, Indonesia, South Africa and Russia 
have become major economies and political powers, international business and entrepreneurs need government to government contacts in many cases to get market access. International business in those cases meets international relations: business representatives and entrepreneurs meet government representatives, especially those in diplomatic service in overseas missions and consulates.

International business has been a fast growing field of academic research and international relations is a well established field of academic research. The two academic fields of study have seldom integrated despite the fact that empirically they are intertwined since they both studied cross-border economic activities. Commercial diplomacy is at the heart of the intersection between international business and international relations. Narrowly conceived, commercial diplomacy is the work of state officials in diplomatic service who carry out activities that support international business. Foreign ministries thus bring professional diplomatic skills and high-level connections to the table in support of the entrepreneur to help explore and secure new business and investment opportunities. Diplomats in overseas missions - from ambassadors to commercial officers - have expert knowledge and experience of the host nation and its economy, as well as useful networks that business can tap into. While we have some knowledge of the commercial activities of foreign ministries and their overseas missions, this is sparse. International relations scholars have largely ignored the commercial aspects of diplomacy and despite the emergence of international political economy there remain only a handful of political scientists studying commercial diplomacy. As such, commercial diplomacy as a field of international relations research has hardly been established, is not well defined, and is in need of more detailed and sustained analysis. We argue that research that integrates international business and international relations would be a very fruitful approach.

\section{The Need of Commercial Diplomacy Research}

Why is there a need for fostering commercial diplomacy as field of research? We live in a global economy, but still with national borders. Business has gone global, but national borders still exist - just ask any would be economic migrant. Of course, the creation of economic regional organizations such as the European Union, the North American Free Trade Agreement, the Southern African Development Community has made business across borders easier. But huge markets such as the Chinese and Indian which are not yet integrated institutionally through regional organizations are not easy to access for international entrepreneurs. In the absence of formal regional institutions, government to government relationship building — that is diplomacy is needed to facilitate more open and easier business access. The commercial advantages to a nation of having an effective network of overseas consulates are well known. Rose's (2007) study of the relationship between the presence of foreign missions and a country's export demonstrated that exports to the host nation rise between 6 and $10 \%$ for each additional consulate. 
The need for transparency pushes diplomacy to open up: tax payers are entitled to know what they get for their money. Embassies and consulates cost money, but what do they bring in? A study of US overseas missions by Wilkinson and Brouthers (2000a, 2000b) demonstrated the economic advantages of American commercial diplomacy and argued that federal states in particular could make far more use of overseas trade missions and trade fairs to help promote exports and FDI.

In a global economy, nations and economic regions are competing for market access, for access to natural resources and for access to procurement markets. That raises the question of how to organize commercial diplomacy effectively and efficiently. Nations have their diplomatic services organized in different ways, and international entrepreneurs are supported in different manners and with different programmes and tools. Perspectives from the field of international relations can help us analyze and understand the political and organizational aspect which business studies accounts have largely ignored.

\section{The Aim of This Book}

This book aims to advance work of this kind as well as other studies of commercial diplomacy by combining insights from two fields of study that to date have hardly spoken to each other. It will bring insights from international relations (and in particular the sub-field diplomatic studies) about the theory and practice of commercial diplomacy and it will bring insights from business studies about the theory and practice of international business. Combining the two, the book, we hope, will better define the field by being more holistic, will bring together in one place a thorough review of existing analysis of the subject from both fields, will outline the basics of a new conceptual framework, will present new empirical work and will put forward a new research agenda. This is ambitious but, we feel, worthwhile since it will help advance current understanding and encourage further analysis of commercial diplomacy as a key (and expanding) phenomenon in the global economy.

This introduction set the stage!

The further outline of the book is as follows:

Chapter 1 is on commercial diplomacy research up to date: what has been published so far on commercial diplomacy, what has been studied empirically so far, what are the results, and what is the road ahead for commercial diplomacy research.

Chapter 2 focuses on the commercial diplomat as the executor of international business support policies and practices. How do commercial diplomats actually work and which factors can help to understand the differences in the ways commercial diplomats work?

Chapter 3 is on the value of commercial diplomacy from an small and medium enterprise (SME) perspective. How do SMEs perceive commercial diplomacy 
services at the foreign post level? What are the factors that explain whether SME value commercial diplomacy?

Chapter 4 presents a study that aim to explain the effectiveness of commercial diplomacy through the eyes of commercial diplomats. What are the factors that influence the quality of commercial diplomacy services?

Chapter 5 continues in this line by presenting a method for measuring export support service efficiency.

Chapter 6 focuses on the interaction between international business executives and commercial diplomats. How do they perceive each other?

Chapter 7 makes a turn to the European Union and presents a comparative study on the European Union member states' commercial diplomacy policies and practices.

Chapter 8 is on the US federal procurement market as a target for foreign firms and the role of commercial diplomacy in it. It presents the results of study on the success factors and barriers for foreign firms to enter the US federal procurement market.

Chapter 9 presents a study on the lobbying tactics of commercial diplomats. How do commercial diplomats at the foreign post level lobby in order to attract international procurement contracts?

\section{References}

Colquitt, J. A., \& George, G. (2011). Publishing in AMJ - part 1: topic choice. Academy of Management Journal, 54(3), 432-435.

Lee, D. (2004). The growing influence of business in UK Diplomacy. International Studies Perspectives, 5, 50-56.

Pigman, G. (2005). Making room at the negotiating table: The growth of diplomacy between nation-state governments and non- state economic entities. Diplomacy and Statecraft, 16, 385-401.

Rose, A. K. (2007). The foreign service and foreign trade: Embassies as export promotion. The World Economy, 30(1), 22-38.

Wilkinson, T. J., \& Brouthers, L. E. (2000a). Trade promotion and SME export performance. International Business Review, 15, 233-252.

Wilkinson, T. J., \& Brouthers, L. E. (2000b). Trade shows, trade missions and state governments: Increasing FDI and high-tech exports. Journal of International Business Studies, 31(4), 725-734. 